\title{
Evaluation of hematological and blood biochemical values in lactating cows in and around Multan city (Punjab), Pakistan
}

\author{
Muhammad Zafar ${ }^{1 *}$, Muhammad Khalil Ahmad Khan², Iram Mushtaq ${ }^{3}$, \\ Samrah Masud ${ }^{4}$, Muhammad Sharjeel Noor ${ }^{5}$, Mohammed Hashir Latif ${ }^{6}$ \\ and Asmatullah ${ }^{7}$ \\ 1. Postgraduate Department of Zoology, Govt. Emerson College, Multan-Pakistan \\ 2. Department of Zoology, University of Okara, Okara-Pakistan \\ 3. Department of Pahtology, University of Veterinary and Animal Sciences, Lahore-Pakistan \\ 4. Department of Zoology, Institute of Pure and Applied Biology, Bahauddin Zakariya University, Multan-Pakistan \\ 5. Quid-e-Azam Medical College, Bahawalpure-Pakistan \\ 6. Multan Medical and Dental College, Multan-Pakistan \\ 7. Department of Zoology, University of The Punjab, Quid-e-Azam Campus, Lahore-Pakistan \\ *Corresponding author's email: m.zafar1214@gmail.com
}

\section{Citation}

Muhammad Zafar, Muhammad Khalil Ahmad Khan, IramMushtaq, SamrahMasud, Muhammad Sharjeel Noor, Mohammed Hashir Latif and Asmatullah. Evaluation of hematological and blood biochemical values in lactating cows in and around Multan city (Punjab), Pakistan. Pure and Applied Biology. Vol. 9, Issue 2, pp1313-1318. http://dx.doi.org/10.19045/bspab.2020.90136

\begin{tabular}{|c|}
\hline Received: 21/11/2019 \\
\hline
\end{tabular}

\section{Abstract}

In this study, hematological and biochemical profile of blood of cows were evaluated to determine the health status. These are highly informative diagnostic tools in collaboration with other diagnostic procedures. The sample of forty cows were equally divided into four groups; early lactation, mid-lactation, late lactation and dry pregnant. These test profiles were compared with the fifth group of ten lactating healthy cows. Early stage of lactating group showed lowered concentration trend $(9.06 \pm 0.34 \mathrm{gm})$ as compared to means in other groups $(9.26 \pm 0.18 \mathrm{gm} \%$ in mid and $10.2 \pm 0.69 \mathrm{gm} \%$ in late). In dry pregnant group the mean value of total leucocyte count (TLC) was $10.03 \pm 0.91 \mathrm{X} 103 / \mathrm{comm}$. showed slightly elevated trend than the normal healthy control group $(8.33 \pm 0.33 X 103 / \mathrm{cmm})$. In dry cows the glucose was significantly higher $(53.68 \pm 4.27 \mathrm{mg} / \mathrm{dl})$ than the early $(38.64 \pm 3.54 \mathrm{mg} / \mathrm{dl})$ and late $(52.48 \pm 5.02 \mathrm{mg} / \mathrm{dl})$ lactating cows. The serum total protein values $(8.26 \pm 0.57 \mathrm{~g} / \mathrm{dl})$ was slightly evaluated as compared to that of the normal healthy control $(8.01 \pm 0.67 \mathrm{~g} / \mathrm{dl})$ during early stage of lactation. Amongst different groups the urea nitrogen values differ significantly $(\mathrm{P}<0.05)$. In dry pregnant cows the descending trend in the serum cholesterol concentration as compared to lactating cows was observed. During early stage of lactation there was drop in calcium level $(8.29 \pm 0.73 \mathrm{mg} / \mathrm{dl})$ than the normal healthy control $(11.25 \pm 0.17 \mathrm{mg} / \mathrm{dl})$. The serum calcium level increased due to the stage of lactation progresses. In different groups of cows the serum magnesium concentration did not differ significantly. The study is helpful for the management and welfare of dairy cows.

Keywords: Blood; Calcium; Cows; Glucose; Lactation; Magnesium; Phosphorus and Protein count 


\section{Introduction}

In dairy cattle farming the health of the cows can be evaluated on the basis of hematological and blood biochemical profile. In bovine medicine, not solely, but in combination with clinical examination or other diagnostic procedures, hematology is known as highly informative as a diagnostic tool [1]. Blood profile metabolites have been used widely for the identification of problems and indication of dietary causes of diseases [2]. For the evaluation of health status of animals the blood biochemical profiles are considered to be most important. In cattle, the estimates of biochemical profile are the prerequisites for the diagnosis of several patho-physiological and metabolites disorders [3]. In animals nutrition is known as the main technological factor that can produce profound different changes in the metabolic profiles [4]. In the diet of the lactating cows, the deficiency of vitamins, proteins and minerals causes different profound changes in metabolism [5]. Within normal physiological limits hematological and biochemical profile reflects a good health status and is highly correlated within milk production [6]. However, environmental factors like temperature and humidity also affect hematological parameters in cows [3]. In lactating cows if there are errors in nutrition only blood parameters analysis can identify them [7]. Based on several factors and by many authors over time, biochemical and hematological parameters of cattle blood were analyzed: influenced of lactation in cows on biochemical profile [8]; the influence of blood biochemical profile in cows as compared between reproductive disorders and clinically healthy cows [9] in dairy cows biochemical variation within the transition period [10] season influence on hematological blood parameters in cows. The present study was undertaken according to the different phases of lactation to study the hematological and some of the blood biochemical changes in cows. In past decades, the shortening of productive life of cows in terms of lactation ranks has less studied with aspect to blood parameters [8].

\section{Materials and methods}

Cows in different stages of lactation (early, mid and late lactation) with a history of drop in a milk production presented for different examination at Veterinary Polyclinic, Multan and different cases identified from local cow farms in and around Multan city were selected for the study comprised of Sahiwal, Dajal, Lohani and Non-Descript breed of cows. The study period was of 10 months. In different stages of lactation in cows detailed clinical examination was performed. The procedure included collection of history in relation to stage of lactation, age, number of lactation, previous and present milk yield and feeding regime. Different clinical parameters were also recorded. Then the cows were divided into four different groups with 10 animals each in their respective period early lactation, mid lactation, late lactation and dry pregnant group. For the comparison of data, a fifth group comprising of 10 lactating cows was observed as healthy control.

Blood samples from these cows were collected in vials from jugular vein and different hematological parameters; Hemoglobin ( $\mathrm{HGb}$ ), Packed Cell Volume (PCV), Total Leucocyte Count (TLC) and Total Erythrocyte Count (ETC) were determined on the same day as per [11]. For biochemical analysis, serum samples were collected in a sterile vial. All the blood biochemical parameters were analyzed by using ADVIA 120 automated analyzer (Bayer Diagnostics, Tarrytown, New York, USA).The statistical analysis was done by applying Completely Randomized Design (CRD).

\section{Results and discussion}

\section{Hematological parameters}

Hematological parameters depicted in (Table 1) showed non-significant differences among 
groups of lactating cows. The mean hemoglobin concentration during early stage of lactation period was found to be $9.06 \pm 0.34$ gm\% which showed lowered trend as compared to that of recorded means in other groups (mid and late) of lactating cows [12]. Similar results were also recorded by [13] in which they found non-significant difference in haematocrit values during the periods of late gestation and early lactation. The mean value of Total Leucocyte Count (TLC) in dry pregnant group of cows was found to be $10.03 \pm 0.91 \times 103 / \mathrm{cmm}$ which showed minutely higher trend as compared to that of normal healthy control group. In some studies [14] reported similar trend of increasing values in lactating cows.

Table 1. Mean \pm S.E. values of hematological parameters according to different Stages of Lactation Periods

\begin{tabular}{|c|c|c|c|c|}
\hline Group & HGB $(\mathbf{g m} \%)$ & PCV $(\boldsymbol{\%})$ & TLC $(\mathbf{X 1 0 3} / \boldsymbol{\mu l})$ & TEC $(\mathbf{X 1 0 6} / \boldsymbol{\mu l})$ \\
\hline Early Lactation Period & $9.06 \pm 0.34$ & $32.2 \pm 1.72$ & $9.14 \pm 0.55$ & $5.79 \pm 0.33$ \\
\hline Mid Lactation Period & $9.24 \pm 0.18$ & $34.4 \pm 3.46$ & $10.17 \pm 0.49$ & $5.37 \pm 0.53$ \\
\hline Late Lactation Period & $10.02 \pm 0.62$ & $37.2 \pm 1.76$ & $9.52 \pm 0.61$ & $5.73 \pm 0.18$ \\
\hline Dry Pregnant & $10.44 \pm 0.62$ & $38.6 \pm 3.77$ & $10.03 \pm 0.91$ & $6.28 \pm 0.42$ \\
\hline Normal Healthy Control & $9.92 \pm 0.32$ & $34 \pm 0.94$ & $8.33 \pm 0.33$ & $6.41 \pm 0.53$ \\
\hline CD & 1.54 & 7.14 & 1.63 & 1.07 \\
\hline F-Value & $1.07 \mathrm{NS}$ & $0.96 \mathrm{NS}$ & $1.75 \mathrm{NS}$ & $1.15 \mathrm{NS}$ \\
\hline
\end{tabular}

HGB: Hemoglobin, PCV: Packed Cell Volume, TLC: Total Leucocyte Count, TEC: Total Erythrocyte Count

\section{Blood biochemical parameters}

According to different stages of lactation blood biochemical parameters depicted in (Table 2) were noted.

\section{Blood glucose level}

In lactated cows, the blood glucose level is considered as one of the indicators of energy status. In dry cows the blood glucose level was significantly higher $(53.68 \pm 4.27 \mathrm{mg} / \mathrm{dl})$ as compared to that of the mid $(47.53 \pm 3.55 \mathrm{mg} / \mathrm{dl})$ and late lactating cows $(52.48 \pm 5.02 \mathrm{mg} / \mathrm{dl})$. In early stage of lactation the lowered means of blood glucose concentrations $(38.64 \pm 3.54 \mathrm{mg} / \mathrm{dl})$ were due to larger amount of blood glucose level withdrawal by the mammary gland for the synthesis of lactose milk [15]. After parturition the hypoglycemia was attributed to heavy drain of glucose level for the synthesis of lactose [16].

\section{Magnesium}

During the metabolism of proteins, nucleic acids, carbohydrates and lipids magnesium plays a vital role. In present study serum magnesium concentration in different groups of cows did not differ significantly. However, in a study [17] recorded higher levels of magnesium $(3.68 \pm 0.25 \mathrm{mg} / \mathrm{dl})$ while in another study [18] noted lowered mean values of magnesium.

\section{Calcium}

During early stage of lactation, there was drop in calcium level $(8.29 \pm 0.73 \mathrm{mg} / \mathrm{dl})$ as compared to that of normal healthy cows $(11.25 \pm 0.17 \mathrm{mg} / \mathrm{dl})$. The depressed trend in $\mathrm{Ca}^{++}$levels may be due to the result of excessive losses through urine, impaired absorption of food metabolites from the gastro-intestinal precursor, clostrums as it was much more drained in the clostrums during excessive drain of milking and this is due to insufficient mobilization from the skeleton. The serum calcium level increased during the stage of lactation progresses which collaborates with the findings of some studies $[16,19]$. In lactating cows in a study [19] noted higher values $(9.88 \pm 0.44)$. 
Table 2. Mean \pm S.E. values of Blood Biochemical Parameters according to stage of lactation period

\begin{tabular}{|c|c|c|c|c|c|c|c|}
\hline Group & $\begin{array}{c}\text { Glucose } \\
(\mathbf{m g} / \mathbf{d l})\end{array}$ & $\begin{array}{c}\text { Magnesium } \\
(\mathbf{m g} / \mathbf{d l})\end{array}$ & $\begin{array}{c}\text { Calcium } \\
(\mathbf{m g} / \mathbf{d l})\end{array}$ & $\begin{array}{c}\text { BUN } \\
(\mathbf{m g} / \mathbf{d l})\end{array}$ & $\begin{array}{c}\text { Cholesterol } \\
(\mathbf{m g} / \mathbf{d l})\end{array}$ & $\begin{array}{c}\text { Total } \\
\text { Protein } \\
(\mathbf{g m} / \mathbf{d l})\end{array}$ & $\begin{array}{c}\text { Phosphorus } \\
(\mathbf{g m} / \mathbf{d l})\end{array}$ \\
\hline $\begin{array}{c}\text { Early } \\
\text { lactation }\end{array}$ & $38.64 \pm 3.54 \mathrm{a}$ & $3.04 \pm 0.38$ & $8.29 \pm 0.73 \mathrm{a}$ & $17.84 \pm 0.69 \mathrm{a}$ & $13.06 \pm 3.51 \mathrm{a}$ & $8.26 \pm 0.57$ & $4.54 \pm 0.63 \mathrm{a}$ \\
\hline $\begin{array}{c}\text { Mid } \\
\text { lactation }\end{array}$ & $47.53 \pm 3.55 \mathrm{~b}$ & $3.11 \pm 0.29$ & $9.74 \pm 0.88 \mathrm{a}$ & $19.63 \pm 1.40 \mathrm{a}$ & $44.36 \pm 7.57 \mathrm{~b}$ & $8.08 \pm 0.62$ & $5.17 \pm 0.55 \mathrm{a}$ \\
\hline $\begin{array}{c}\text { Late } \\
\text { lactation }\end{array}$ & $52.48 \pm 5.02 \mathrm{a}$ & $3.18 \pm 0.94$ & $8.63 \pm 0.48 \mathrm{a}$ & $22.82 \pm 1.20 \mathrm{~b}$ & $37.43 \pm 7.87 \mathrm{~b}$ & $7.48 \pm 0.69$ & $4.66 \pm 0.24 \mathrm{a}$ \\
\hline $\begin{array}{c}\text { Dry } \\
\text { (Pregnant) }\end{array}$ & $53.68 \pm 4.27 \mathrm{a}$ & $2.86 \pm 0.32$ & $7.71 \pm 1.04 \mathrm{a}$ & $24.08 \pm 0.78 \mathrm{c}$ & $14.18 \pm 5.75 \mathrm{a}$ & $8.18 \pm 0.72$ & $4.65 \pm 0.52 \mathrm{a}$ \\
\hline $\begin{array}{c}\text { Healthy } \\
\text { Control }\end{array}$ & $50.04 \pm 0.53 \mathrm{a}$ & $3.48 \pm 0.15$ & $11.25 \pm 0.17 \mathrm{~b}$ & $25.74 \pm 0.45 \mathrm{~b}$ & $88.35 \pm 3.18 \mathrm{c}$ & $8.01 \pm 0.67$ & $6.44 \pm 0.32 \mathrm{~b}$ \\
\hline CD & 9.77 & 0.78 & 2.04 & 2.78 & 15.88 & 1.52 & 1.17 \\
\hline F-value & $2.92 \mathrm{~S}$ & $0.46 \mathrm{NS}$ & 3.55 & $12.32 \mathrm{HS}$ & $14.79 \mathrm{HS}$ & $0.33 \mathrm{NS}$ & $2.25 \mathrm{~S}$ \\
\hline
\end{tabular}

$\mathrm{S}-$ Significant at $5 \%$ level $(\mathrm{P}<0.05), \mathrm{NS}-$ Non-significant, $\mathrm{HS}-$ Highly significant at $1 \%$ level $(\mathrm{P}<0.01)$

\section{Blood urea nitrogen (BUN)}

Among the different groups of lactating cows the blood urea nitrogen values differ significantly $(\mathrm{P}<0.05)$. In early lactating stage the mean blood was significantly lowered as compared to that of normal healthy control cows $(25.74 \pm 0.45 \mathrm{mg} / \mathrm{dl})$. After parturition, [20] noted lowered urea concentration which stimulates with the present values. In dry pregnant cows in late pregnancy, increased in blood urea could be either due to increased protein intake or increased de-amination [21].

\section{Cholesterol}

In dry pregnant cows as compared to that of lactating cows, the descending trend in the serum cholesterol concentration was observed [22]. Following calving and got build up as the lactation progressed, the serum total cholesterol concentration was found to be lesser [23]. With the advancement of lactation the higher level of cholesterol was found to be a physiological adjustment to meet the requirements of lactation. During pregnancy the hormonal level of estrogen along with thyroxin played in important role in reducing the cholesterol levels [19].

\section{Total proteins}

During early stage of lactation period the serum total protein values $(8.26 \pm 0.57 \mathrm{~g} / \mathrm{dl})$ was minutely evaluated as compared to that of the normal healthy control $(8.01 \pm 0.67 \mathrm{~g} / \mathrm{dl})$. In some studies [22] noted lowered concentration of total proteins as compared to that of recorded in the present investigation. Due to dietary intake of concentrates higher serum total protein concentration might have been associated with infectious processes i.e. metritis and mastitis have improved.

\section{Phosphorus}

In early stage of lactation the serum phosphorus level $(4.54 \pm 0.63 \mathrm{mg} / \mathrm{dl})$ was significantly $(\mathrm{P}<0.05)$ lowered as compared to that of the normal healthy control and other groups of cows. Moderate depression in the levels of phosphorus was due to the necessity of its for enhanced carbohydrate metabolism and colostrums synthesis [24].

\section{Conclusion}

Mostly the dairy farms in Pakistan are located in rural areas and thus facing several challenges regarding the controls and management. The results of this study provide baseline knowledge about the lactating cows to show the different stages of 
lactation influence the blood biochemical and hematological parameters in dairy cows.

\section{Authors' contributions}

Designed the study and carried out the laboratory experiments: M Zafar, Performed the experiments: Asmatullah, Participated in sample and data collection: MKA Khan, Provided guidance and coordination for study design: MH Latif \& MS Noor, Analyzed the data: I Mushtaq \& S Masud, Wrote the paper: M Zafar.

\section{Acknowledgement}

The authors thank the study participants for their involvement in the study. The authors also thank Muhammad Muzammil, Ahmed Dawood, Muhammad Moosa and Muhammad Hamza for helping in sample collection.

\section{References}

1. Roland L, Drillich $\mathrm{M}$ \& Iiversan $\mathrm{M}$ (2018). Hematology as a diagnostic tool in bovine medicine. J Vet Diag Inv 26(5): 592-598.

2. Lee AJ (1988). Blood Metabolic Profile: Their use and Relation to Nutritional Status of Dairy Cows. J Dairy Sci 61: 1652-1670.

3. McDowell LR (1992). Minerals in animal and human nutrition. Academic Press. Inc San Diego, California.

4. Ingvasten KL (2006). Feeding and management related diseases in the transition cow Physiological adaptations around calving and strategies to reduce feeding related diseases. Animal Feed Sci and Technol 126: 175-213.

5. Parvu G (2007). Supravegherea nutritional-metabolic animal. $J$ Anim Feed Sci 9: 411-424.

6. Coroian A, Matea CT, Vodnar DC \& Coroian CO (2019). Biochemical and hematological profile in cattle effective. Bulletin UASVM Vet Med 71(1): 27-30.

7. Payne JM, Dews SM, Manston RI \& Margaret F (1997). The use of a metabolic profile test in dairy herds. Vet Record 87: 150-158.

8. Fillipejova T \& Kovacik J (2009). Evaluation of selected biochemical parameters in blood plasma, urine and milk of dairy cows during the lactation period. Slovak J Anim Sci 1: 8-12.

9. Ruginoen E, Careanga S, Safronie M, Malancus R, Boghian V \& Solcan G (2011). The biochemical profile in cow with reproductive disorders. Cercetai Agron in Moldova Vol. XLIV No. 2(146).

10. Imhasly S, Naegei H \& Luch A (2014). Metabolic biomarkers correlating with hepatic lipidosis in dairy cows. BMC Vet Res 2014(10): 122.

11. Benjamin MM (2001). Outline of Clinical Veterinary Pathology, $2^{\text {nd }}$ Edition. Kalayani Publishers, New Delhi - Ludhiana, pp 31, 35-36, 51, 62, 71, 187-189, 203.

12. Tambare PK (2005). Studies on hypoglycemia with particular reference to Metabolic Profile in Buffaloes. M.V.Sc. Thesis submitted to MAFSU, Nagpur.

13. Flores A, Althaus R, Toibero JC, Gamero OJ \& Perren L (2013). Metabolic profile of dairy cow before and after parturition. Revista-ArgentinaDe-production Animal 10(4): 289-293.

14. Deshpande SD, Sawant MK \& Vadalamudi VP (2018). Leucocytic studies in Sahiwal and crossbreed cattle. Indian Vet J 65: 791-796.

15. Scultz LH (1998). Ketosis in dairy cow. J Dairy Sci 51: 1133-1140.

16. Nale RA (2003). Metabolic profiling in cows before and after parturition. M.V.Sc. Thesis submitted to MAFSU, Nagpur, pp 29-34.

17. Rao DG (1981). Studies on some biochemical constituents of blood in Ongole cows. Ind Vet J 870-873. 
18. Gupta GC \& Rai P (1997): a note on biochemical profile in pre and post partum states in cattle and buffalos. Indian J Vet Med 7: 45-46.

19. Rowland GJ (1998). Changes in albumin, globulin, glucose and cholesterol concentration in a blood of dairy cows in a late pregnancy and early lactation. J of Agri Sci (Cambridge) 94: 517-527.

20. Poso AR \& Lindberg LA (1994). Plasma protein synthesis and serum amino-acids in dry and lactating dairy cows. $J$ Vet Med Series A 41(1):72-75.
21. Oliva G, Tranquillo A \& Persechino A (1991). Blood chemistry of primiparous and pluriparous buffalo-cows in late pregnancy and at the start of lactation. Acta Medica Vet 35(2): 207-217.

22. Nath HC (2005). Serum cholesterol and protein in pre, peri and postpartum cows. Indian Vet J 82: 519-521.

23. Kulkarni BA (1993). Biochemical studies in GIr and Crossbreed dairy cows. Indian Vet J 60: 17-22.

24. Rook JAF \& Thomas PC (2016). Nutritional physiology of farm animals. Ed. 1. Longman In. New York. 